\title{
Capital stock in Spain and its distribution by territories (1964-2012)
}

\author{
Matilde Mas, Francisco Pérez, Ezequiel Uriel ${ }^{1}$ \\ ${ }^{1}$ Instituto Valenciano de Investigaciones Económicas and University of Valencia, Valencia, Spain \\ Received: 5 February 2015/Accepted: 5 February 2015
}

Abstract. This resource describes a data source for investment, capital stock and capital services data for Spain and Spanish territories for the period 1964 to 2012.

Key words: Spain, investment, capital, territorial distribution

\section{Description of the Resource}

Since 1995, the BBVA Foundation and the Valencian Institute of Economic Research (Ivie) have been conducting an extensive research program on Spanish economic growth. The regularly updated database, Capital stock in Spain and its distribution by territories, is the basis of this program, providing information on the accumulation of capital in Spain over the last four decades.

Figure 1: Sample screen shots.

(a) Main page

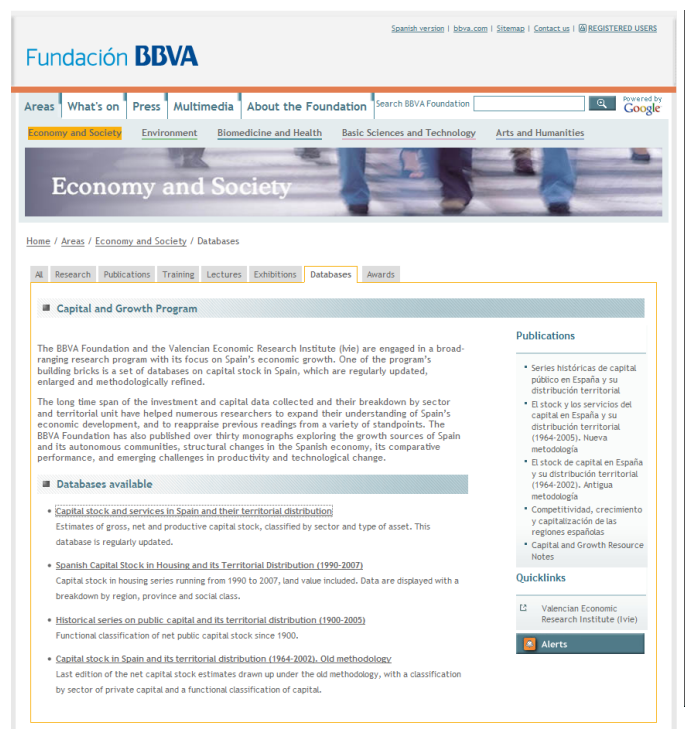

(b) Data presentation

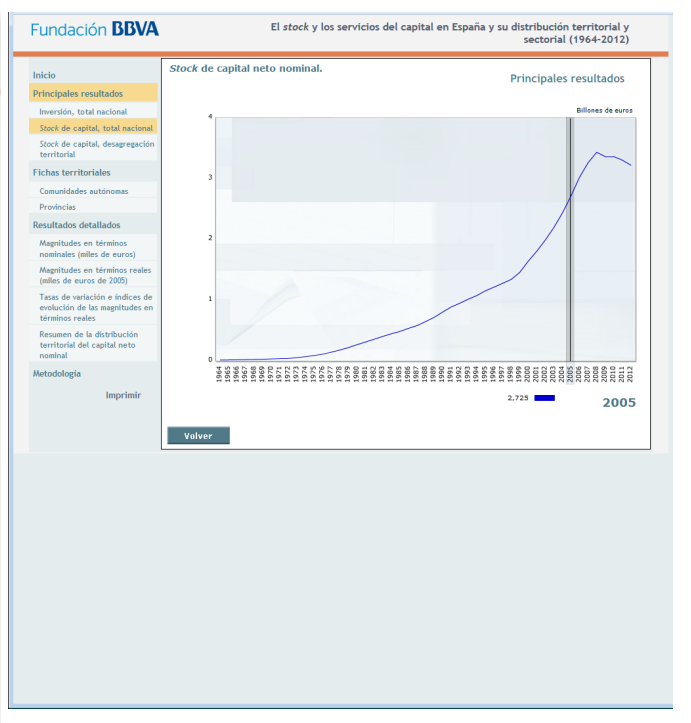


The capital stock estimates included in this database derive from the most recent methodological orientation, developed by the OECD in 2001 and revised in $2009 .{ }^{1}$ The series on investment and capital stock offer a wealth of information with multiple disaggregation covering long periods of time by asset type, industry, and institution (public and private). The series also contain territory-specific information, grouped according to Spain's 17 autonomous communities, 2 autonomous cities (Ceuta and Melilla), and 50 provinces.

The database offers information for three variables: Gross fixed capital formation, net capital stock (wealth), and capital services. The capital series are computed following the perpetual inventory method (PIM).

The database considers 18 different asset types, distinguishing between tangible and intangible assets. In addition, this classification includes three information and communication technology (ITC) assets (software, hardware, and communications) and offers a great asset breakdown in public infrastructures (road infrastructures, public water infrastructures, rail infrastructures, airport infrastructures, port infrastructures, and local corporation and urban infrastructures), which is a distinctive characteristic of these BBVA Foundation-Ivie series.

At the national level, 31 industries are considered, following NACE Rev. 2 classification. In addition, data by autonomous communities and provinces are disaggregated into 18 types of assets, and 25 and 15 industries, respectively - significantly enriching the information that the database makes available for researchers and other users.

The magnitudes are expressed in millions of current and constant (base year 2005) euros. The online database also provides the Törnqvist indexes and growth rates for net capital stock and capital services.

This extensive database, which the BBVA Foundation and the Ivie have made available to the public, is accompanied by numerous dynamic graphs that facilitate the analysis of the evolution and composition of capital endowments in Spain and its territories since the middle of the nineteenth century. Moreover, the database's update is usually complemented with a report analyzing the data and summarizing the main results.

The series on investment and capital stock coming from the BBVA Foundation-Ivie estimates have been incorporated into the OECD Productivity database by industry (PDB) and in the OECD STructural ANalysis Database (STAN).

The next database release, which will cover up to 2013, is expected to be published by the second half of 2015 .

\section{$2 \quad$ Resource links}

- http://www.fbbva.es/TLFU/tlfu/ing/areas/econosoc/bbdd/capital2007.jsp

\footnotetext{
${ }^{1}$ Full details of the methodological criteria followed can be found in El stock y los servicios del capital en España y su distribución territorial y sectorial en el periodo 1964-2012 (CNAE 2009).
} 